\title{
Sustainability as an Effective Tool for a Place Branding: An Application on El Gouna City, Egypt
}

\author{
Sherine El Sakka
}

\begin{abstract}
Most developing countries consider sustainability is a luxury, but El Gouna city at hurghada, Egypt, thought differently and uses sustainability as a tool for branding the place. Branding a place is new approach towards sustainable cities development (SCD); sustainability(S) requires multi-dimensional indicators to show the relationship between economic, social, environmental and cultural aspects. Sustainable development (SD) defined as meeting the needs of current generations without negative impact on the needs of future generation, branding a place (BP) integrate economic, social, environmental and cultural aspects into the city. In order for a city to be a good brand it must possess distinctive characteristics that can be identified, these include city appearance, people's experience, people's belief as well as what the city stands for. The study has found that place branding is a way to promote sustainable initiative; place branding has the potential to shape as a leading tool for the concurrence of more sustainable cities in developing countries, sustainability and green development should turn main priorities to developing countries.
\end{abstract}

Index Terms-Sustainable cities development (SCD), sustainability(S), sustainable development (SD), branding a place (BP).

\section{INTRODUCTION}

Developing countries are obliged to compete in the international market for their survival, they have to be an attractive touristic place, building a strong image is one of the contemporary a city should pursuit. To develop sustainable city, a city image should be changed, its structure, activities, culture and building, should be promoted. The study will explore the ways El Gouna city applied to brand itself as a sustainable city and how a good branding could assist in making city desirable by a cooperation effort between el Gouna city residents and el Gouna management, Orascom group for hotel.

\section{A. Sustainability}

According to the United Nations World Commission on Environment and Development (The Brundtland Commission) report, sustainability is defined as the ability to create development that meet the needs of the present generation without compromising the ability of future generations to meet their own needs " the ability to sustain life at the current quality for the generations that come after ours (1987:43) Sustainability implies the protection of non-renewable resources at an acceptable cost to benefit the society and the

Manuscript received May 5, 2015; revised January 29, 2016.

Sherine El Sakkam is with the Department of management, School of Business, Future University, Egypt (e-mail: sherinesakka@ fue.edu.eg). state.

\section{B. Sustainable Development}

According to the Rio Declaration on Environment and Development Agenda 21 in 1992, sustainable development became a global strategy for planning professionals, architects and development officials to address human developments effects on the environmental crisis [1].

\section{Urban Branding}

The concept of urban branding it's a process of differentiation and diversification whereby local tourism organizations, arts and culture facilities, museums, historic preservations group help producing tourist sites to attract consumers and investment to a particular local area. Urban branding could be through buildings signature, events or through urban redevelopment, City branding means the main things that should people know about certain place. Places get to be real brand when its visitors feel the distinctive of its identity mark [2].

\section{Urban Branding Aims}

- Develop new ways of communicating city image to the world.

- Achieve competitive advantages regionally and internationally.

- Strengthen the reputation of the city and its corporate identity that improve its economic importance [3].

\section{E. City Branding}

City branding has to be concerned with how culture and history, economic growth and social development, infrastructure and architecture, landscape and environment, Branding is a deliberate strategy to select some attributes of a product as core values in order to facilitate the process by which consumers confidently recognize and appreciate those attributes [4] argue that the concept of product branding can be transplanted to city branding. A city can be viewed as an "entity", to whom an "identity "is ascribed with a set of stable values fostered from the long course of urban development [5] A city can generate utility functions that "customers" (investors, visitors and the resident population) can experience through daily business transactions and related activities. Cities therefore could be marketed, through tourism development and through branding activities. One crucial strategy within city branding is the creation of the city's identity, which should be developed from a range of several variables such as history, demography, economy, politics and policies. A city usually has certain identifiable images or core values perceived by its people. For example, Paris is perceived for romance, Milan for style, New York for diversity and dynamics, Washington for power, and Tokyo 
for modernity. A big challenge to city branding thus lies in creating and profiling an identity from diverse values that are not always intangible and that may represent different interests of various social groups in the city, a strategy of city branding is to create unique values, so distinguishing one city from another. While city authorities are responsible for the implementation of city branding, people communicate their experience with the city acting as "ambassadors". City branding conveys both the intention of city authorities and the experience of people [6].

\section{F. Brand City Characteristics}

The idea of destination branding appeared in 1996 with the first academic conference, the first article tackled this subject was late 1990 and the first book published concerning this issue was 2002.

A slogan is very important for marketing a destination the slogan of el Gouna life as it should be, it's very important that the slogan is understandable for all market segments. Branding a city is not a promotion according to Anhott (2006) describes a frame work of evaluating city brand (hexagon) the six contents of the hexagon are place, presence, potential, pulse, people and prerequisites, presence refers to how familiar people are with the city and its international status , place how the city is pleasant and how its sights are beautiful, potential, how the city can offer in term of economic, the pulse how is the urban status of city, people examine how people are warm and how is the safety factor are, perquisites, the standard, accommodation, price .City branding needs to synthesize various characteristics [7]. A key challenge of city branding is the difficulty of delimiting a city's identity and core values in a manner that is widely acceptable, easily marketable, presentable and open to experience. In this regard, strategies of product branding maybe less appropriate in the context of a city where ownership, stakeholder involvement and branding development are more complex [8].

Brand city must have the following:

- Have a reasonable climate

- Have a reasonable public transportation

- Provide good and affordable houses

- Have good schools as well as recreational and cultural attractions

\section{G. Key Factors for a City to Brand its Image Successfully}

City attempt to establish a target market and a loyal customer, when branding a city the personality of its residents is an essential part of the brand, if the city succeeded to make its community satisfied that create positive brand image for both cities and community. The purpose of branding is to achieve a consumer perception that deliver a sustainable competitive advantage in order for a brand to be strong it must be functional, it means benefits are observable, a city must function as a destination for employment, housing, public transportation and recreation attraction, for instance, El Gouna city possess all of these functions, [9] for example an individual does not need a car to get around in El Gouna all of its distinctive attractions are available by means of walking, taxis and tock tock, real brands provide not only functional benefits but nonfunctional added value, added value translates into loyalty and this loyalty is key determining the success of the brand. The functionality and added value of El Gouna city has original functional properties such as restaurants, attractions, reputation, weather, farm, mineral water factory, internationals schools, varieties of hotels, El Gouna city it's highly distinctive, El Gouna people have diverse backgrounds, interests and Tastes. In order for a city to have a brand, it has to stand for something, El Gouna stand for being environmental friendly city [10].

\section{H. Urban Branding Objectives}

1) Strengthen the reputation of the city

2) Achieve competitive advantages nationally and internationally

\section{EL Gouna City, Case Study}

Recently some cities have begun to focus on nature as a tool to strengthen their brand or redirect it and this was the case of El Gouna in Hurghada Egypt. This was, established in 1990, and located 25 kilometers north of Hurghada, a 4-hour flight from Europe's major capitals and 30 minutes flight from Cairo. The town is easily accessed from Europe via Hurghada International airport; its location offers good access to Egypt's historical and archeological treasures. The ancient temples of Luxor and Aswan are only a bus away. Day and overnight trips to Luxor, Aswan, Cairo, and Sinai could be arranged from El Gouna. It is a distinctive brand which offers many things for tourists to enjoy including culture, commerce, attractions, restaurants and entertainment. El Gouna Beach resort, has been officially recognized as the country's most environmentally friendly holiday destination. The resort town aims to become the country's and the continent's first carbon-neutral city. With a joint Egyptian-Italian project, El Gouna will use renewable energy from windmill farms. This agreement will help the Egyptian government to achieve a significant breakthrough in the fields of environment and tourism, enhancing Egypt's global image and opening the door for Egyptian tourism projects and to rank city among the leading carbon-neutral entities," said Dr. Laila Iskandar, Egyptian ex Minister of State for Environmental Affairs. Government estimates place current total greenhouse gas emissions of tourist establishments in Egypt at around 3.5 million tons of carbon dioxide. According to the agreement signed at the end of December 2013, the environmental ministry is responsible for providing technical support, on the other hand the tourism ministry is accountable for standards setting and marketing while the Ministry of Electricity and Power is tasked with supplying the clean energy. Ex Minister of Tourism Hisham Zaazou said "the initiative will be rolled out to more towns and cities across Egypt. Sharm El Sheikh is set to be the next carbon-neutral destination, with Soma Bay, Ras Ghareb and Marsa Alam also planning to go green". Municipalities around the globe are already racing to land the title of world's first carbon-neutral city, including Masdar, UAE and Seattle, U.S. El Gouna is one of the cleanest places you can find in Egypt. The streets are so clean there is trash buckets placed around the town a different bucket for different types of trash. Recycling bins in all public areas are installed, El Gouna community now has a "zero-waste system," whereby over 85 percent of all waste is recycled and reused. They established a waste recycling plant, wastewater 
management systems, a water desalination plant; El Gouna has taken upon itself to have a Green Festival to celebrate Earth Day. El Gouna city is committed to promoting initiatives with the aim of minimizing environmental impacts, such as the use of renewable energies in residential and collective sectors, the use of treated sewage water in planting green spaces ,re-use and recycling $85 \%$ of waste and implementation of local grow organic products.

"We see Gouna turning into a renewable energy laboratory," said Sheriff Abdel Messih, Chief Executive Officer of Future Energy Corporation. "Even things we can't use are recycled, compressed, and turned into tiles for sidewalks."

The city's organic waste is used as fertilizer for plants and gardens. To set standards as a model for environmental sustainability, El Gouna has adopted the "green initiative," which aims to use renewable energy as much as possible.

According to Abdel Messih, "El Gouna hotels as well as residents also use solar water heaters, which can be found on almost every building in the city." Abdel Messih added that solar panels are not expensive, in the long-run, renewable energy is much more beneficial as fuel prices are increasing and fossil fuels are diminishing. The government makes it easier and cheaper for people to use electricity, gas, and diesel; however we are running out of fossil fuels, so we should take advantage of the renewable energy that we have."

Instead of relying on the government for water pipelines, El Gouna treated seawater in order to make the best of their resources. There is also domestic water reverse with water saving nasals that help reduce consumption. To grow organic products locally, El Gouna farm was certified by Suolo e Salute, an Italian control certification body for food industry and environment. Companies approved by Suolo e Salute are allowed to export their organic products directly to key markets around the world. Suolo e Salute is accredited by the United States Department of Agriculture for the USDA-NOP label and the Ministry of Agriculture of Japan as well as the Canadian Food Inspection Agency.

El Goanna's fish farm, established in 2000, use rejected water from desalinating units. There are 10 connected fishponds, three duck houses to help fertilize the farming water, and two separate shrimp ponds, in the farm, there are also ponds containing Acacia, Eucalyptus, and Mangrove plants, which can tolerate the desert climate and salty soil. As a result of their sustainable programs, Green Globe International, which is a non-profit organization, promotes environmentally and socially responsible tourism has awarded El Gouna resort. In December 2010, the resort also received first prize for best environmental practices from Saudi Arabia's Environmental Management in a ceremony that was held at Bibliotheca Alexandrina.

In a lavish ceremony in Bogota, Colombia, El Gouna City has received the Global Green City award sponsored by the United Nations Environment Program. This award is handed to cities displaying substantial measures and efforts in progress within the field of environmental sustainability, especially cities that adhere to a strict environment conservation plan and employ different mechanisms for sustainability and a greener community. El Gouna is the first city to receive this award locally as well as the first in Africa and the Arab Region. This prestigious award has been handled before by the Global Forum on Human Settlements to several cities around the world such as Santa Monica in the United States, Vancouver in Canada, Nantes in France, Yokohama in Japan and Rockdale in Australia. It honors cities, companies and individuals taking serious steps for a greener more sustainable environment. There were 8 cities competing for the award, the appraisal committee selected 3 cities to get the award El Gouna (Egypt), Vancouver (Canada) and Liaoning (China).

El Gouna is currently discussing their "Green Star" program with the Ministry of Tourism. The program, which will rate hotels based on how environmentally friendly they are, is to encourage other hotels to start adopting greener policies. For 20 years El Gouna has been adopting these practices, and it is now one of the greenest cities in Egypt and the Middle East, if one city in Egypt can do it, the Egyptian government can be motivated to apply these practices elsewhere. El Gouna organizes eco-friendly events to help promote healthy and renewable living in Egypt. Engineer Samih Sawiris, Chairman and Chief Executive Officer of Orascom Development Holding, explained, "El Gouna has been working on a complete plan to create a clean, green and unique environment. The plan entails several actions to lower carbon emissions as well as to use a clean renewable energy, and to reduce electricity consumption in addition to employ energy saving techniques."

The plan uses several mechanisms and protocols such as replacing traditional street lighting with energy saving lights and replacing diesel based public transportation vehicles with electricity using vehicles. On the other side, Sawiris Foundation for Environmental Development is working at El Gouna on employing suitable successful endeavors to become a pioneer in green economy and sustainability in Egypt and Africa. These efforts will help to build a unique tourism destination in Egypt as El Gouna now combines both breathtaking scenery and a safer green environment; it makes Egypt one of the top tourist attractions.

The vision of Engineer Samih Sawiris is to turn $50 \mathrm{~km}$ of open desert on Egypt's east coast to a green, luxurious and environmentally-friendly top Red Sea destination. On March 1, 2014, the Red Sea resort town of El Gouna launched an eco-friendly fleet of hybrid cars to provide a full suite of transport services operated by Budget company the fleet's vehicles which include taxis, rental cars, limousines and shuttles combine a petrol engine with an electric motor, all around El Gouna, the cars can run on electricity alone, thus reducing carbon emissions. Budget's transport services, available to residents and visitors as well, it will ease getting around the resort town, which sprawls over 10 kilometers of coastline interwoven with lagoons and islands. The transport can also be hired for trips outside El-Gouna. The initiative is a result of a partnership between El-goanna's mother company Orascom development and Ezz El arab automotive, and Budget rent a Car's as a sole agent in Egypt.

Dr. Laila Iskandar, Ex Minister of State for Environmental Affairs signed with Mr.

Clini Corrado the Italian Ministry of Environment, and 
Mr. Sameih Sawiris on behalf of city of El Gouna in Hurghada a protocol of joint program for sustainable management and carbon neutral for a period of 3 years. The protocol aim is to support transforming the city of El Gouna towards low-carbon emissions through the analysis of the current energy consumption and to integrate low-emission measurements of carbon.

This protocol will develop several activities, including the analysis of inventory of greenhouse gas emissions of the city to identify its main sources and determine these measurements to reduce these emissions and to integrate it with additional programs which are implemented in the site such as energy efficiency, energy conservation in buildings and electric vehicles and management of low-carbon resources and water recycling.

A steering committee has been formed to ratify the work program end of January 2014and to identify the initiatives that will be implemented to accomplish the goals and to fix the timetable of implementation, forms of technical support and monitoring.

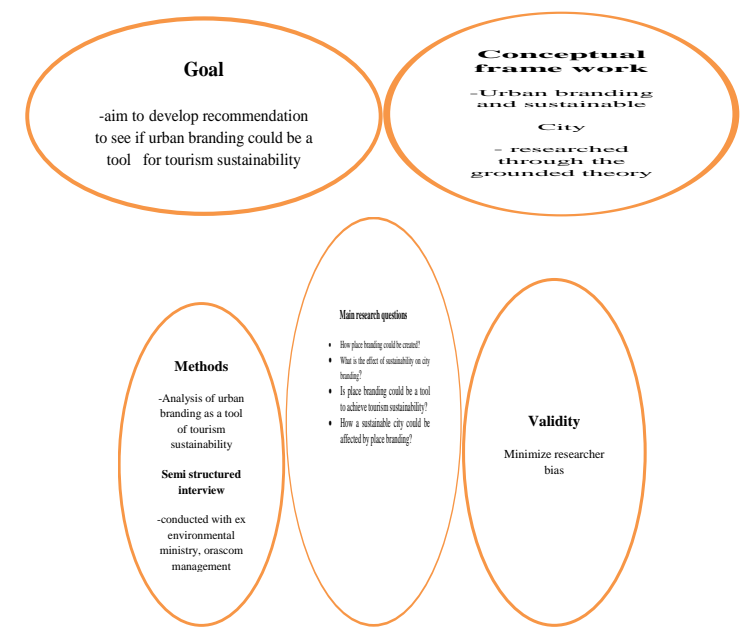

Fig. 1. Research design adopted from Maxwell 2005.

\section{RESEARCH PROBLEM}

Sustainable city development could be a tool affects the place branding; we question how sustainability could be used to brand and change an image of a place and how these brands contribute to sustainable regional development. It's important to understand the relation between place branding and sustainable development, there has been a research on place branding as a tool for sustainable development (Maheshwari et al. 2011) he underlines that scholars agree that place brands are multifaceted but they fail to clarify those facets and their impact to sustainable development in the urban development.

\section{A. Research Questions}

Based on the above mentioned research problem, the following research questions are raised

- How place branding could be created?

- What is the effect of sustainability on city branding?

- Is place branding could be a tool to achieve tourism sustainability?

- How a sustainable city could be affected by place branding?

\section{B. Research Objective}

The objective of this paper is to examine the effectiveness of El Gouna branding by reviewing theoretical insights discussed in the literature and by investigating the understanding of the general public vis a vis the city, The principal objective of this paper is to emphasize the role the place branding plays in sustainable city development, the increased awareness and importance of place branding is partly fuelled by the idea that sustainability is no longer relied On natural resources or infrastructure only. To address the preceding research questions the objectives of this paper are as follows

- To explore how place branding could be created

- To examine the effect of sustainability on city branding

- To discuss how place branding could be a tool to achieve tourism sustainability

- To assess how sustainable city could be affected by place branding

\section{Research Methodology}

The methodology adopted by the research is interpretative, in this paper, a research investigation where a combination of exploratory which were based on case study research and descriptive parts which will deep the understanding of different variables, periodicals, articles, books, press release personal experience and residents, employees' interviews.

The data collection was done through observation, interview sessions, with selected tourism stakeholders, the study population was divided into manageable groups within the tourism industry in order to select the sample frame of the study. Three industry experts were interviewed. The interview schedule had structured, semi structured and unstructured questions which sought to gather stakeholder's experiences, perceptions, motivations, and the perceived state of tourism resources. The structured questions sought to measure infrastructure and services, environmental factors, perceptions, the role of city residents, media and the key elements emphasized in the brand.

An analysis of all the information sources gathered from both primary and secondary was tailed. The paper explores the concept of sustainability as a tool of branding a place in one of the developing country .The research will focus on El Gouna city in hurghada, Egypt.

\section{DATA COLLECTION}

The method used for the data collection is interviews, which will provide us with information about the place branding policies applied in El Gouna, without interviews it will be impossible to access this information; this method will give the reader an idea of the goals and the future of the place. Interviewing is an appropriate for the study because of its capacity of gathering informations, opinions and beliefs; it's very handy and consistent way Conducting interviews is a quite popular and suitable choice [11].

\section{CONCEPTUAL Frame Work}

Grounded theory was applied through this study as a 
qualitative research methodology we relied on two conceptual frame work to guide and inform our research (the sustainable city model) (Giffinger et al. 2007) which present six characteristics under which a sustainable city should aim to develop and the (Anhott GFK nation brands index NBI 2005, 2008) Simon Anholt started the nation brands index 2005 and parented up with the GFK in 2008; nation brand is discussed with regard to six criteria: exports, tourism, people, culture and heritage, investment and immigration and governance

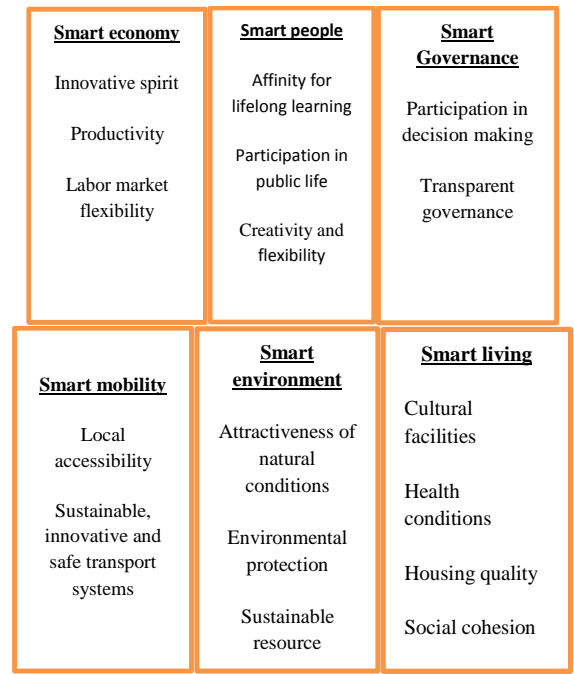

Fig. 2. Six characteristics of sustainable city model (Giffinger et al. 2007).

\section{A. The Interviews}

Were based on questionnaire, divided in two groups, group covers branding the place and group covers the sustainability of the city.

\section{B. Interviews Structure}

The interview focused on the importance of the urban branding and how it could be used as a sustainable tool to attract tourists, the participants were asked to describe some of the sustainable projects at el Gouna and to clarify the citizens' roles in this mission, and then they expressed their own opinion concerning the urban branding as a tool for tourism sustainability.

The interviews were conducted in person during a week visit to EL Gouna, the interview varied between 20 to 30 minutes for each interviewee, followed by trip field.

\section{Data Analysis}

The method followed for the process is theoretical studying [12], according to it the interviews based on the researchers personnel opinion reflection concerning the topic. The result of the case study analyzed through the mentioned procedure.

\section{Study Result}

The results will be discussed under two categories; the first category will be according to the professions of the interviewers and the second category will be according to questions theme.

\section{QUESTIONS THEME}

Interviewers were asked about El Gouna branding project, citizens' roles and tourism sustainability

\section{El Gouna URBan BRANDING Project}

According to the interviewee El Gouna city ideally located has its own schools, a university (Berlin Campus of El Gouna) which could be an incentive for young generation to stay in the city, it has also its own hospital and medical centers, shopping centers, El Gouna use renewable energies in residential and collective sectors, it use treated sewage water in the planting of green spaces and installed recycling bins in all public areas.re-use and recycle $85 \%$ of waste and implementation of local grow organic products. Its future plan entails actions to lower carbon emissions.

\section{El Gouna Citizens’ Roles}

El Gouna citizen have a strong presence they collaborate to comply with all the rules and regulations established by Orascom group for hotels and management to reach the city to be a better sustainable place.

\section{TOURISM SUSTAINABILITY}

El Gouna adopted an infrastructure system which prevent traffic congestions, its plan to create a co2 emissions neutral city, it use also solar cells in all El Gouna roofs as a way of fighting climate change by lower down emissions, we asked interviewee if marketing el Gouna as a sustainable city could be a way to promote the city and to attract tourists as well to attract investment, they confirmed that sustainability projects in middle east is a new approach but yes it would attract tourism and investment, and they see that keeping innovative projects could attract a lot of attention to the city as well.

El Gouna received the Global Green City Award in August 2014. Sponsored by the United Nations Environment Program, which made el Gouna the first destination in Africa and the Arab Region to receive this kind of awards, this award is handed to cities displaying substantial measures and efforts in progress within the field of environmental sustainability.

Mövenpick El Gouna received Green Globe Awards gave by Green Globe International, an organization that promotes environmentally and socially responsible tourism., El Gouna selected as the pilot location for the Green Star Hotel Initiative.

\section{CONCLUSION}

The paper aim is to contribute to the discussion of how sustainability could be a tool for branding a place by investigating El Gouna life we found that the six characteristics of sustainable city according to( Giffinger model 2007 )are available at el Gouna, el Gouna is a productive place over 2700 villas and apartments sold, has a flexible labor market over 400 restaurants ,bars and commercial outlets, it has a competiveness factor, it has a human capital which they participate in public life with creativity and flexibility, Orascom group for hotel and management as the owner of el Gouna they are transparent 
and give the resident of the place the chance to participate with them in the decision making, the transportation at El Gouna is available either taxi with reduced carbon emission or the tok tok, El Gouna protect the environment in all aspect it protect as well the environment by preserving its natural resources ,there is a quality of living at el Gouna it's a healthy place with housing quality .

According to Anhott city brand criteria El Gouna ready to compete with unlimited resource it's a well-established tourist hotspots suitable for varied tourist interests, from excellent diving and snorkeling to cultural and historical locations .It has a stunning natural and unspoiled landscape, it has 18 hotels with capacity of 2707 rooms, three marinas, 18 hole championship golf course, library, 4 schools, 2 universities, it has warm desert climate with temperatures ranging from $14^{\circ} \mathrm{C}$ in winter to $30^{\circ} \mathrm{C}$ in summer, El Gouna has a steady annual growth in tourist figures beside the enormous European interest in properties located on the Red Sea. Which encourage by the flexibility of investment law in Egypt demonstrated by the disappearance of capital gains tax, Low registration fees, No inheritance tax, beside living and maintenance low cost

The results shown that El Gouna city could use the sustainable measurements as tool to brand itself and succeeded to create a healthy living environment that attracted tourists, finally sustainability has the possibility to be a tool for branding a place.

\section{RECOMMENDATION}

As a recommendation for further researches we propose to apply the experience of el Gouna on other cities either in Egypt or on other developing countries to attract more tourists aiming to help them to effectively and efficiency move their cities towards sustainability and to use sustainability to brand their image .

\section{REFERENCES}

[1] Zeemering, "Collaborative strategies for sustainable cities," p. 135 2009.

[2] J. Jansson and D. Power, "Urban branding as constructed capabilities in Nordic city regions," Institutional and Infrastructure Support, p. 16, October 2006

[3] Kavaratzis, "Brand management for cities," Journal of Brand Management, pp. 520-531, 2009.

[4] W.-P. Julia, "The branding of cities," August, Syracuse University, pp. $10,15,16,2005$.

[5] K. Gotham, "Branding the big easy, tourism rebuilding in post Katrina," Urban Affairs Rev., pp. 42, 82, 83, 2007.

[6] L. Mak. "Branding partners \& levit advertising, " pp. 20-22, April 21, 2003.

[7] M Helmy, "Urban branding strategy and the emerging arAb cityscape, The image of the gulf city," PhD Study, Stuttgart University, Stuttgart, 2008.

[8] R. Unworthy, "Rebranding the city, changing the image of places and spaces," GA Lectures, Geographical Association School of Geography, University of Leeds, England, 2008

[9] S. Piks, "Tourism destination, branding, complexity," Journal of Product \& Branding Management, vol. 14, no. 4, pp. 258-259, 2005.

[10] M. Kavartzis, "Cities and their brands, lessons from corporate branding," December 2007.

[11] Giffinger, 2007.

[12] Kvale \& Brinkmann, 2009

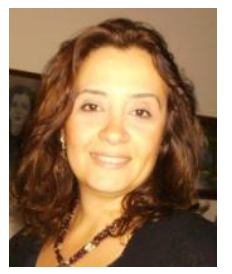

Sherine El Sakka got the $\mathrm{PhD}$ in environmental science 2008. She is an assistant professor at Canadian International College from 2008 till 2011. She is the head of Quality Unit at Faculty of Commerce and Business Administration, Future University. She is also the head of Mentoring Unit at Faculty of Commerce and Business Administration Future University. She got the Awareness of Environmental Aspects in Solving the Solid Waste Management Problems - An Overview on Egypt. 